\title{
ANALISIS STATUS PEMANFAATAN SUMBER DAYA IKAN SEBAGAI DASAR PENGELOLAAN PERIKANAN TANGKAP BERKELANJUTAN DI WILAYAH PERAIRAN CIREBON
}

\author{
Pigoselpi Anas', Luky Adriantoº, Ismudi Muchsin'², dan Arief Satria² \\ ${ }^{1}$ Mahasiswa pada Fakultas Perikanan dan IImu Kelautan IPB-Bogor \\ ${ }^{2}$ Komisi Pembimbing pada Fakultas Perikanan dan Ilmu Kelautan IPB-Bogor \\ Teregistrasi I tanggal:23 Mei 2011; Diterima setelah perbaikan tanggal: 22 Agustus 2011; \\ Disetujui terbit tanggal: 30 September 2011
}

\begin{abstract}
ABSTRAK
Pada dasarnya pengelolaan perikanan tangkap bertujuan untuk mewujudkan usaha perikanan tangkap yang berkelanjutan. Untuk itu, laju penangkapan ikan harus tidak melebihi potensi produksi lestari (Maximum SustainbleYield, MSY) dari sumber daya ikan dalam suatu wilayah perairan. Namun, pengelola perikanan di Indonesia umumnya berpandangan, bahwa menentukan MSY dan hasil tangkapan ikan di laut susah dan mahal. Dengan metode Surplus Production Model, penelitian ini dimaksudkan untuk mengetahui status pemanfaatan sumber daya ikan berdasarkan pada jenis alat tangkap, zona penangkapan ikan, dan jenis ikan secara lebih mudah dan murah di wilayah perairan laut Kabupaten Cirebon. Penelitian dilakukan dari Oktober 2010 sampai Maret 2011. Hasil penelitian menunjukkan, bahwa status pemanfaatan sumber daya ikan baik di Zona-I, ZonaII maupun Zona-III perairan laut Cirebon pada umumnya telah mengalami gejala tangkap lebih (overfishing). Dari 13 jenis alat tangkap yang digunakan oleh nelayan di daerah penelitian, tujuh diantaranya yakni payang, dogol, pukat arad, jaring insang hanyut, jaring insang lingkar, bagan tancap, dan rawai tetap statusnya sudah melebihi dari jumlah upaya optimum $\left(\mathrm{f}_{\text {opt }}\right)$. Sedangkan, enam jenis alat tangkap lainnya, yaitu pukat tarik, jaring insang tetap, jaring kantong, anco, perangkap kerang, dan perangkap lainnya statusnya masih kurang. Adapun jenisjenis ikan yang telah mengalami overfishing adalah: teri, teri nasi, bawal hitam, sunglir, gurita, biji nangka, kapas-kapas, slanget, sotong, kurisi, kuniran, peperek, kurau, ikan sebelah, cumi-cumi, manyung, tetengkek, bawal putih, talang, kakap, tongkol, tenggiri, cucut, japuh, tembang, julung-julung, siro, bilis, pari, alu-alu, dan remang.
\end{abstract}

KATAKUNCI: potensi produksi lestari, surplus production model, tangkap lebih, underfishing, laut Cirebon

ABSTRACT: Analysis of the State of Fisheries Resource Utilization as a Basis for the Management of Sustainable Capture Fisheries in Cirebon Marine Waters. By : Pigoselpi Anas, Luky Adrianto, Ismudi Muchsin, and Arief Satria

Management of capture fisheries is basically intended to achieve economic activities of capture fisheries on a sustainable basis. Accordingly, the exploitation rate of fisheries resources should not exceed its MSY (Maximum Sustainable Yield) in a marine area. Unfortunately, majority of fisheries management authorities in Indonesia perceive that determining MSY and total fish catch in marine waters is both difficult and expensive. By employing Surplus Production Model, this research aims at evaluating the state of fisheries resource utilization based upon the types of

Kampus IPB Darmaga, Jl. Raya Darmaga, Bogor, Jawa Barat. 
fishing gears, fishing zones, and types of fish stocks in Cirebon marine waters, which is easier and less expensive than it is currently perceived by those management authorities. The results of this research demonstrate that the state of fisheries resources in Zone-I, Zone-II, and Zone-III of Cirebon marine waters has generally been overfishing. Furthermore, among 13 types of fishing gears used in Cirebon marine waters, seven fishing gears are already exceeding the optimum fishing effort $\left(f_{\text {opp }}\right)$. These include mini purse seine, danish seine, fish net, gill nets, encirling gill nets, fixed lift net, and long lines. Meanwhile, the other six fishing gears including active purse seine, fixed gill nets, trammel nets, anco, trap for molluscs, and other trap types are still less than their optimum number. Amongst so many fish species caught from Cirebon marine waters, thirty one specieas are already overfishing, which include teri, teri nasi, bawal hitam, sunglir, gurita, biji nangka, kapas-kapas, slanget, sotong, kurisi, kuniran, peperek, kurau, ikan sebelah, cumicumi, manyung, tetengkek, bawal putih, talang, kakap, tongkol, tenggiri, cucut, japuh, tembang, julung-julung, siro, bilis, pari, alu-alu, dan remang.

KEYWORDS: maximum sustainable yield, surplus production model, overfishing, underfishing, Cirebon marine waters

\section{PENDAHULUAN}

Permasalahan mendasar yang sampai sekarang masih dihadapi bangsa Indonesia adalah tingginya angka pengangguran dan kemiskinan. Oleh karena itu, setiap sektor pembangunan, tidak terkecuali sektor kelautan dan perikanan, dituntut untuk meningkatkan kontribusinya bagi pertumbuhan ekonomi yang berkualitas untuk menciptakan lapangan kerja dan meningkatkan kesejahteraan masyarakat secara berkelanjutan. Bagi sub-sektor perikanan tangkap, misi pembangunan itu harus ditafsirkan secara bijaksana, karena jika peningkatan kontribusi ekonomi hanya diartikan sebagai upaya untuk memacu tingkat penangkapan ikan, tanpa menjaga kelestariannya, maka akan mengakibatkan terjadinya overfishing (tangkap lebih), kepunahan jenis, yang berujung pada ambruknya usaha perikanan tangkap itu sendiri.

Pada tahun 2010 total produksi ikan dari seluruh wilayah perairan laut Indonesia, termasuk ZEEI (Zona Ekonomi Eksklusif Indonesia), tercatat sebesar 5,058 juta ton (KKP, 2011) atau sekitar $77,8 \%$ dari potensi produksi lestari (MSY) sebesar 6,520 juta ton/tahun (Komnas Kajiskan, 2010). Menurut FAO Code of Conduct for Responsible Fisheries (1995), bahwa untuk menjamin kelestarian stok ikan, maka tingkat penangkapan ikan harus tidak melebihi $80 \%$ dari nilai $M S Y$ di suatu wilayah perairan. Dengan demikian, secara umum status pemanfaatan sumber daya ikan laut Indonesia saat ini sebenarnya sudah mendekati kondisi tangkap lebih (overfishing). Lebih dari itu, sudah banyak wilayah perairan laut yang stok ikannya telah mengalami overfishing, terutama di Pantai Utara Jawa, Selat Malaka, Pantai Selatan Sulawesi, dan Selat Bali.

Sejak era otonomi daerah pada 2001, laju eksploitasi sumber daya ikan laut bahkan semakin meningkat dan cenderung mengabaikan aspek konservasi. Apabila pola penangkapan ikan laut semacam ini tidak segera diperbaiki, maka dikhawatirkan banyak stok ikan laut di wilayah perairan Indonesia akan mengalami overfishing, hasil tangkap per satuan upaya (catch per unit of effort) dan pendapatan nelayan menurun, dan pada gilirannya usaha perikanan tangkap itu sendiri akan gulung tikar, alias tidak berkelanjutan. 
Untuk mengubah pola perikanan tangkap yang tidak berkelanjutan tersebut menjadi perikanan tangkap yang berkelanjutan, pertama yang harus dilakukan adalah memastikan bahwa laju penangkapan setiap stok ikan tidak melebihi nilai MSY di setiap unit wilayah pengelolaan perikanan. Namun, sampai saat ini informasi tentang MSY dan hasil tangkapan ikan hanya tersedia secara agregatif, yakni menurut kelompok sumber daya ikan (pelagis besar, pelagis kecil, demersal, udang penaeid, ikan karang konsumsi, lobster, dan cumi-cumi) untuk sebelas WPP (Wilayah Pengelolaan Perikanan) yang terdapat dalam wilayah perairan laut Indonesia, termasuk ZEEI. Padahal, seiring dengan era otonomi daerah/desentralisasi, kewenangan pengelolaan wilayah laut (termasuk sumber daya ikan di dalamnya) dari garis pantai sampai 4 mil laut sudah menjadi kewenangan pemerintah kabupaten/kota, dan wilayah laut dari 4 mil sampai 12 mil merupakan kewenangan pemerintah provinsi (UU No. 32/2004 tentang Pemerintahan Daerah). Oleh karena itu, informasi tentang nilai MSY dan hasil tangkapan ikan seharusnya tersedia untuk setiap wilayah perairan laut yang menjadi kewenangan pengelolaan pemerintah provinsi dan kabupaten/kota di seluruh Indonesia.

Sampai sekarang, masih sangat sedikit informasi tentang MSY dan produksi ikan menurut jenis sumber daya ikan maupun per wilayah perairan laut yang menjadi kewenangan pengelolaan pemerintah kabupaten / kota maupun pemerintah provinsi. Akibatnya, hampir semua pengelolaan perikanan tangkap di laut di daerah kabupaten/kota maupun provinsi tidak berdasarkan pada data dan informasi ilmiah tersebut. Pada umumnya para pengelola perikanan tangkap di tingkat kabupaten/kota maupun di provinsi berpandangan, bahwa menentukan MSY per jenis ikan, menurut jenis alat tangkap maupun per zona di wilayah perairan laut yang menjadi kewenangannya adalah sesuatu yang secara teknis sulit untuk dilakukan dan secara finansial mahal.

Penelitian ini ditujukan untuk menentukan status pemanfaatan sumber daya ikan di wilayah perairan laut Kabupaten Cirebon, Provinsi Jawa Barat menurut jenis alat tangkap, jenis ikan, dan zona penangkapan ikan. Kabupaten Cirebon dipilih sebagai lokasi penelitian, karena karakteristik ekologi laut, perikanan tangkap, dan permasalahan nya dapat mewakili daerah perikanan lainnya di sepanjang Pantai Utara Jawa. Hasil penelitian ini diharapkan bisa menjadi terobosan (breakthrough) bagi para pengelola perikanan untuk dengan cara yang relatif mudah dan murah mengelola pembangunan perikanan tangkap berbasis informasi ilmiah secara berkelanjutan .

\section{STATUS PEMANFAATAN SUMBER DAYA IKAN BERDASARKAN JENIS ALAT TANGKAP}

Atas dasar perhitungan SPM, jumlah alat tangkap optimum yang dapat dioperasikan $\left(f_{o p t}\right)$ di wilayah perairan laut Cirebon agar kelestarian sumber daya ikan tetap terpelihara untuk setiap jenis alat tangkap disajikan pada Tabel 1. Sementara itu, menurut Dinas Kelautan dan Perikanan Kabupaten Cirebon (2010), jumlah unit setiap alat tangkap yang kini digunakan oleh nelayan $\left(f_{\text {existing }}\right)$ di daerah penelitian pada tahun 2009 (data terakhir yang tersedia) adalah seperti yang disajikan juga pada Tabel 1. 
Tabel 1. Status tingkat pemanfaatan sumber daya ikan berdasarkan penggunaan jenis alat tangkap di Perairan Laut Cirebon.

Table 1. Status of the utilization level of fisheries resources by types of fishing gears in Cirebon Marine Waters.

\begin{tabular}{clccl}
\hline No. & Jenis Alat Tangkap & $\begin{array}{c}\mathbf{f}_{\text {opt }} \\
\text { (unit) }\end{array}$ & $\begin{array}{c}\text { Jumlah Alat Tangkap } \\
\text { Existing (unit) } \\
\text { Th. 2009 }\end{array}$ & $\begin{array}{l}\text { Status } \\
\text { Penggunaan } \\
\text { Alat tangkap }\end{array}$ \\
\hline 1. & Pukat tarik ikan & 2.395 & 622 & Kurang \\
2. & Payang & 510 & 793 & Berlebih \\
3. & Dogol & 8 & 138 & Berlebih \\
4. & Pukat arad /apolo & 74 & 206 & Berlebih \\
5. & Jaring Insang Hanyut & 379 & 472 & Berlebih \\
6. & Jaring Insang Lingkar & 33 & 592 & Berlebih \\
7. & Jaring Insang Tetap & 4.861 & 1.475 & Kurang \\
8. & Trammel Net & 3.495 & 2.014 & Kurang \\
9. & Bagan Tancap & 48 & 192 & Berlebih \\
10. & Anco & 1.881 & 64 & Kurang \\
11. & Rawai Tetap & 15 & 233 & Berlebih \\
12. & Perangkap Kerang & 328 & 277 & Kurang \\
13. & Perangkap Lainnya & 2.463 & 667 & Kurang \\
\hline
\end{tabular}

Selanjutnya, status tingkat pemanfaatan sumber daya ikan (SDI) menurut jenis alat tangkap dikatakan berlebih, apabila $\mathrm{f}_{\text {existing }}$ lebih besar dari pada $f_{\text {opt }}$. Sebaliknya, apabila $f_{\text {existiting }}$ lebih kecil dari pada $f_{\text {opt }}$, maka statusnya adalah kurang. Berdasarkan kriteria ini, maka dapat diketahui bahwa dari 13 jenis alat tangkap yang digunakan oleh nelayan di daerah penelitian, tujuh diantaranya yakni payang, dogol, pukat arad (apolo), jaring insang hanyut, jaring insang lingkar, bagan tancap, dan rawai tetap statusnya sudah berlebih. Sedangkan, enam jenis alat tangkap lainnya, yaitu pukat tarik, jaring insang tetap, jaring kantong (trammel net), anco, perangkap kerang, dan perangkap lainnya statusnya masih kurang.

Berdasarkan hasil wawancara dengan 400 responden nelayan, bahwa ketujuh alat tangkap yang telah mengalami kondisi berlebih tersebut memang secara umum lebih efisien dari pada keenam alat tangkap lainnya yang masih kurang. Artinya, para nelayan Cirebon seperti nelayan lain di berbagai belahan dunia pada umumnya memang melakukan kegiatan penangkapan ikan sesuai dengan naluri ekonominya, yakni menggunakan alat tangkap yang lebih efisien atau menguntungkan (Berkes, et al., 2001). Namun, jika kegiatan perikanan tangkap tidak dikendalikan atau dibatasi (open access), maka cepat atau lambat akan terjadi overfishing yang berakhir dengan ambruknya usaha perikanan tangkap itu sendiri.

Oleh sebab itu, untuk memelihara kelestarian sumber daya ikan dan juga keberlanjutan usaha perikanan tangkap agar dapat mensejahterakan nelayan di daerah penelitian, maka jumlah unit ketujuh jenis alat tangkap yang berstatus berlebih itu harus dikurangi sampai jumlahnya sama dengan atau lebih kecil dari pada $f_{\text {opt }}$, tepatnya $80 \%$ dari $_{\text {opt }}($ FAO, 1995). 


\section{STATUS SUMBER DAYA IKAN BERDASARKAN ZONA PENANGKAPAN IKAN}

Di perairan Laut Jawa, termasuk di perairan Laut Kabupaten Cirebon, aktivitas penangkapan ikan pada umumnya menggunakan berbagai jenis alat tangkap yang menangkap berbagai macam jenis ikan (Potier and Sadhotomo, 1995). Dengan perkataan lain, perikanan di Laut Jawa bersifat multigears dan multispecies. Sementara itu, satu jenis alat tangkap dapat beroperasi di beberapa zona penangkapan ikan. Oleh karena itu, perlu dilakukan identifikasi dan pemetaan lokasi operasi setiap jenis alat tangkap pada zona yang ada di perairan daerah penelitian, sehingga dapat diketahui jenis-jenis alat tangkap yang beroperasi di masing-masing zona tersebut. Jenis-jenis alat tangkap yang beroperasi di masing-masing zona penangkapan ikan di perairan laut Cirebon berdasarkan pada hasil wawancara dan observasi lapang disajikan pada Tabel 2.

Tabel 2. Sebaran operasi setiap jenis alat tangkap di Zona-1, Zona-II, dan Zona-III di Daerah Penelitian.

Table 2. Distribution of fishing gears used in Zone-I, Zone-II, and-Zone-III of the Study Area.

\begin{tabular}{|c|c|c|c|}
\hline \multirow{2}{*}{ Alat Tangkap } & \multicolumn{3}{|c|}{ Zona } \\
\hline & I (0 - $4 \mathrm{mil})$ & II (4 - 12 mil) & III (>12 mil) \\
\hline Pukat tarik & & $\sqrt{ }$ & \\
\hline Payang & & $\sqrt{ }$ & \\
\hline Dogol & $\sqrt{ }$ & & \\
\hline Pukat arad /apolo & $\sqrt{ }$ & $\sqrt{ }$ & \\
\hline Jaring Insang Hanyut & & $\sqrt{ }$ & $\sqrt{ }$ \\
\hline Jaring Insang Lingkar & & $\sqrt{ }$ & \\
\hline Jaring Insang Tetap & $\sqrt{ }$ & & \\
\hline Trammel Net & $\sqrt{ }$ & $\sqrt{ }$ & \\
\hline Bagan Tancap & $\sqrt{ }$ & & \\
\hline Anco & $\sqrt{ }$ & & \\
\hline Rawai Tetap & & $\sqrt{ }$ & \\
\hline Perangkap Kerang & $\sqrt{ }$ & & \\
\hline Perangkap Lainnya & $\sqrt{ }$ & & \\
\hline
\end{tabular}

Kemudian, informasi tentang status pemanfaatan sumber daya ikan berdasarkan alat tangkap dari Tabel 1 dimasukkan ke Tabel 2, maka secara indikatif dapat kita ketahui status sumber daya ikan laut di Zona-I, Zona-II, dan Zona-III perairan laut Cirebon seperti tercantum pada Tabel 3. 
Tabel 3. Status sumber daya ikan laut di tiga zona penangkapan ikan di daerah penelitian.

Table 3. Status of marine fisheries resources within three fishing zones of the study area.

\begin{tabular}{lccc}
\hline \multicolumn{1}{c}{ Alat Tangkap } & \multicolumn{3}{c}{ Zona } \\
\cline { 2 - 4 } & I (0-4 $\mathbf{~ m i l )}$ & II (4-12 mil) & III (>12 mil) \\
\hline Pukat tarik ikan & & $\begin{array}{c}\text { Underfishing } \\
\text { Overfishing }\end{array}$ & \\
Payang & Overfishing & & \\
Pukol & Overfishing & Overfishing & \\
Jaring Insang Hanyut & & Overfishing & Overfishing \\
Jaring Insang Lingkar & & Overfishing & \\
Jaring Insang Tetap & Underfishing & & \\
Trammel Net & Underfishing & Underfishing & \\
Bagan Tancap & Overfishing & & \\
Anco & Underfishing & & \\
Rawai Tetap & & Underfishing & \\
Perangkap Kerang & Underfishing & & \\
Perangkap Lainnya & Underfishing & & \\
\hline
\end{tabular}

Atas dasar informasi dari Tabel 3, maka dapat diketahui bahwa overfishing telah terjadi baik di Zona-I, Zona II, maupun ZonaIII. Selain itu, aktivitas nelayan paling banyak berlangsung di Zona-I, dimana 8 jenis alat tangkap beroperasi, yakni dogol, pukat arad, jaring insang tetap, trammel net, bagan tancap, anco, perangkap kerang, dan perangkap lain. Kemudian diikuti di ZonaII, dimana 7 jenis alat tangkap beroperasi, yaitu pukat tarik, payang, pukat arad, jaring insang hanyut, jaring insang lingkar, trammel net, dan rawai tetap. Sementara itu, di Zona-III hanya beroperasi satu jenis alat tangkap, yaitu jaring insang hanyut, yang statusnya juga sudah overfishing. Gambaran ini juga sesuai dengan hasil wawancara dengan para responden, yang menyatakan bahwa hampir semua nelayan $(98,25 \%)$ di wilayah penelitian beroperasi menangkap ikan di Zona-I dengan rata-rata waktu melaut 2,83 jam (Tabel 4), atau bersifat one-day fishing 
Tabel 4. Lama Operasi Nelayan Melaut dan Zona Penangkapan Ikan Table 4. The Fishing Time of Fishermen and their Fishing Grounds

\begin{tabular}{|c|c|c|c|c|c|c|c|}
\hline \multicolumn{4}{|c|}{1 Hari Melaut } & \multicolumn{4}{|c|}{$>1$ Hari Melaut } \\
\hline $\begin{array}{l}\text { Jumlah } \\
\text { Responden }\end{array}$ & $\%$ & $\begin{array}{c}\text { Rata-rata } \\
\text { Waktu } \\
\text { melaut (jam) }\end{array}$ & $\begin{array}{l}\text { Fishing } \\
\text { Ground }\end{array}$ & $\begin{array}{l}\text { Jumlah } \\
\text { Responden }\end{array}$ & $\%$ & $\begin{array}{c}\text { Rata-rata } \\
\text { Waktu } \\
\text { melaut } \\
\text { (hari) }\end{array}$ & Fishing Ground \\
\hline 393 & 98,25 & 2,83 & Zona 1 & 7 & 1,75 & 3 & $\begin{array}{l}\text { Karimun Jawa, } \\
\text { Surabaya, Laut } \\
\text { Sumatera, Jakarta, } \\
\text { Muara Bendera } \\
\text { (Bekasi), } \\
\text { Lampung, Karimun } \\
\text { (Semarang),P.Ker } \\
\text { amean } \\
\text { (Semarang), } \\
\text { Belitung, Tg. } \\
\text { Kalimantan, } \\
\text { Sampit, Mandalika }\end{array}$ \\
\hline
\end{tabular}

\section{STATUS SUMBER DAYA IKAN BERDASARKAN JENIS IKAN}

Berdasarkan hasil perhitungan dengan SPM melalui standarisasi berbagai jenis alat tangkap yang beroperasi di perairan Cirebon, maka didapatkan nilai MSY sumber daya ikan di wilayah penelitian sebesar $52.718,4$ ton per tahun (Tabel 5) yang dihitung dari model Schaefer (Gambar 1).

Tabel 5. Nilai MSY sumber daya ikan laut berdasarkan Model Schaefer di Daerah Penelitian.

Table 5. MSY Value of marine fisheries resource based on SchaeferModel in the Study Area.

\begin{tabular}{cc}
\hline Parameter & Schaefer Value \\
\hline A & $2,690,200$ \\
B & $-0,3432$ \\
F msy & 391,93 \\
MSY & $52.718,36$ \\
R2 & 0,5661 \\
TAC & $4,217,468,555$ \\
\hline
\end{tabular}

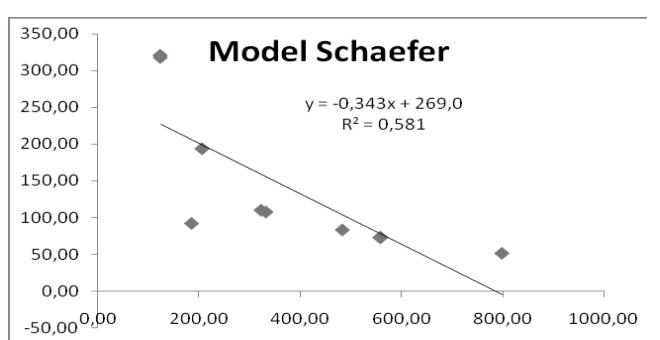

Gambar 1. Nilai MSY sumber daya ikan laut berdasarkan Model Schaefer di Daerah Penelitian.

Figure 1

Sementara itu, hasil tangkapan ikan menurut jenis alat tangkap yang beroperasi di daerah penelitian pada tahun 2009 tercatat sebesar 35.770,60 ton (Tabel 6).

Selanjutnya, dengan memasukkan informasi dari Tabel 6 ke Tabel 2, maka diperoleh hasil tangkapan ikan di masingmasing zona penangkapan seperti disajikan pada Tabel 7. 
Tabel 6. Volume hasil tangkapan menurut jenis alat tangkap tahun 2009

Table 6. Production volume of fish by types of fishing gears in 2009.

\begin{tabular}{clc}
\hline No. & \multicolumn{1}{c}{ Alat Tangkap } & Produksi Tahun 2009 (ton) \\
\hline 1. & Pukat tarik ikan & $2.257,4$ \\
2. & Payang & $1.022,8$ \\
3. & Dogol & $11.888,5$ \\
4. & Pukat arad/apolo & 0 \\
5. & Jaring Insang Hanyut & $9.676,4$ \\
6. & Jaring Insang Lingkar & 86,3 \\
7. & Jaring Insang Tetap & 840,2 \\
8. & Trammel Net & $1.534,2$ \\
9. & Bagan Tancap & 90,2 \\
10. & Anco & 0 \\
11. & Rawai Tetap & $4.047,2$ \\
12. & Perangkap Kerang & $3.627,3$ \\
13 & Perangkap Lainnya & 700,1 \\
\hline \multicolumn{2}{c}{ Total } \\
\hline
\end{tabular}

Tabel 7. Volume ikan hasil tangkapan di Zona-I, Zona-II, dan Zona-III pada 2009 Table 7. Production volume of fish in Zone-I, Zone-II, and Zone-III in 2009.

\begin{tabular}{|c|c|c|c|c|}
\hline \multirow{2}{*}{ No. } & \multirow{2}{*}{ Alat Tangkap } & \multicolumn{3}{|c|}{ IKan Hasil Tangkapan per Zona (ton) } \\
\hline & & $\mathrm{I}(0-4 \mathrm{mil})$ & II (4 - $12 \mathrm{mil})$ & III (>12 mil) \\
\hline 1. & Pukat tarik ikan & & $2.257,4$ & \\
\hline 2. & Payang & & $1.022,8$ & \\
\hline 3. & Dogol & $11.888,5$ & & \\
\hline 4. & Pukat arad/apolo & & 0 & \\
\hline 5. & Jaring Insang Hanyut & & $4.838,2$ & $4.838,2$ \\
\hline 6. & Jaring Insang Lingkar & & 86,3 & \\
\hline 7. & Jaring Insang Tetap & 840,2 & & \\
\hline 8. & Trammel Net & 767,1 & 767,1 & \\
\hline 9. & Bagan Tancap & 90,2 & & \\
\hline 10. & Anco & 0 & & \\
\hline 11. & Rawai Tetap & & $4.047,2$ & \\
\hline 12. & Perangkap Kerang & $3.627,3$ & & \\
\hline 13 & Perangkap Lainnya & 700,1 & & \\
\hline & Total & $17.913,4$ & $13.019,0$ & $4.838,2$ \\
\hline
\end{tabular}


Berdasarkan pada jumlah upaya tangkap (total fishing effort) yang beroperasi pada masing-masing zona, maka didapatkan nilai MSY pada masing-masing zona seperti tercantum pada Tabel 8 .

Tabel 8. Nilai MSY dan hasil tangkapan tahun 2009 pada setiap zona penangkapan ikan di daerah penelitian.

Table 8. MSY Value and production volume in 2009 by fishing zones in the study area.

\begin{tabular}{ccc}
\hline Zona & $\begin{array}{c}\text { MSY } \\
\text { (ton/tahun) }\end{array}$ & $\begin{array}{c}\text { Hasil Tangkapan } \\
\text { (ton) (Tahun 2009) }\end{array}$ \\
\hline I $(0-4 \mathrm{mil})$ & $26.998,00$ & $17.913,40$ \\
II $(4-12 \mathrm{mil})$ & $22.656,80$ & $13.019,00$ \\
III $(>12 \mathrm{mil})$ & $3.063,60$ & $4.838,20$ \\
\hline Total & $\mathbf{5 2 . 7 1 8 , 4 0}$ & $\mathbf{3 5 . 7 7 0 , 6 0}$ \\
\hline
\end{tabular}

Dari Tabel 8 tampak bahwa volume hasil tangkapan ikan existing (data tahun 2009) di Zona-1 dan Zona-II, tingkat penangkapannya masih lebih rendah dari pada nilai MSY-nya, sedangkan di Zona-III tingkat penangkapan lebih tinggi dari pada MSY. Namun, volume_hasil tangkapan existing yang lebih rendah dari pada nilai MSY bukan hanya memiliki arti uderfishing, tetapi juga bisa berarti overfishing tergantung pada nilai f-nya (model parabolik Schaefer) (Gulland, 1983; Charles, 2001). Apabila nilai $f_{\text {existing }}$ tersebut lebih kecil dari pada dari $f_{\text {opt }}$ maka berarti status sumber daya ikannya masih underfishing. Sebaliknya, apabila nilai $\mathrm{f}_{\text {existing nya }}$ lebih besar dari $f_{o p t}$, maka status sumber daya ikannya sudah overfishing. Mengingat bahwa sebagian besar $f_{\text {existing }}$ baik berdasarkan alat tangkap maupun zona penangkapan itu lebih besar dari pada $\mathrm{f}_{\text {opt }}$ (Tabel 1 dan 3 ), maka dapat disimpulkan, bahwa status sumber daya ikan berdasarkan stok ikan di daerah penelitian secara umum sudah mengalami overfishing.
Status sumber daya ikan di daerah studi yang telah overfishing tersebut juga sesuai dengan hasil wawancara dengan 400 responden (Tabel 9), dimana sebagian besar mereka $(69,75 \%)$ menyatakan bahwa volume tangkapan ikan semakin kecil dan sebanyak $68,25 \%$ responden menyatakan ukuran ikan yang tertangkap semakin kecil dalam lima tahun terakhir. Selain itu, mayoritas $(71,25 \%)$ responden merasakan bahwa jumlah waktu yang diperlukan untuk menangkap jumlah ikan yang sama semakin lama.

Setelah diketahui sebaran operasi masing-masing alat tangkap pada zonasi yang ada, maka kemudian dapat ditentukan sebaran jenis-jenis ikan pada setiap zona berdasarkan informasi komposisi hasil tangkapan pada setiap alat tangkap yang beroperasi di masing-masing zona tersebut (Tabel 10). Dari Tabel 10, dapat diketahui status pemanfaatan jenis-jenis ikan yang ada di Perairan Laut Cirebon pada masingmasing zona.

Dari Tabel 10 dapat disimpulkan bahwa berdasarkan jenis-jenis ikan, sebagian besar sudah mengalami overfishing. Beberapa jenis ikan yang belum mengalami overfishing adalah jenis-jenis ikan yang ditangkap dengan alat tangkap sederhana seperti pukat tarik, jaring insang tetap dan trammel net. Selain itu, jenis-jenis ikan tersebut merupakan jenis-jenis ikan yang mempunyai habitat di perairan pasang surut atau perairan pantai yg cukup subur, sehubungan dengan perairan pesisir Cirebon yang merupakan muara dari 30 sungai. Akan tetapi jenis-jenis ikan yang ditangkap menggunakan alat tangkap yang cukup modern seperti payang, dogol, pukat arad/apolo, jaring insang hanyut, jaring insang lingkar dan bagan tancap sudah mengalami overfishing. 
Tabel 9. Kecenderungan volume hasil tangkapan, ukuran ikan hasil tangkapan, dan jumlah waktu yang diperlukan untuk melaut.

Table 9. Trend of catch, size of fish catch, and required fishing time.

\begin{tabular}{ccccccc}
\hline \multirow{2}{*}{ Deskripsi } & \multicolumn{2}{c}{ Volume Tangkapan } & \multicolumn{2}{c}{ Ukuran Ikan } & \multicolumn{2}{c}{ Waktu yang Diperlukan } \\
\cline { 2 - 7 } & $\begin{array}{c}\text { Jumlah } \\
\text { Responden }\end{array}$ & $\%$ & $\begin{array}{c}\text { Jumlah } \\
\text { Responden }\end{array}$ & $\%$ & $\begin{array}{c}\text { Jumlah } \\
\text { Responden }\end{array}$ & $\%$ \\
\hline Semakin Kecil & 279 & 69,75 & 185 & 68,25 & 62 & 15,5 \\
Semakin & 43 & 10,75 & 35 & 8,75 & 285 & 71,25 \\
Besar & 78 & 19,5 & 180 & 23 & 53 & 13,25 \\
Sama Saja & $\mathbf{4 0 0}$ & $\mathbf{1 0 0}$ & $\mathbf{4 0 0}$ & $\mathbf{1 0 0}$ & $\mathbf{4 0 0}$ & $\mathbf{1 0 0}$ \\
\hline Jumlah & & & & & &
\end{tabular}

Tabel 10. Sebaran jenis-jenis ikan dan jenis alat tangkapnya pada masing-masing zona dan status pemanfaatannya di perairan Cirebon.

Table 10. Distribution of fish species and the type of gear in each zone and the status of its utilization in the waters of Cirebon.

\begin{tabular}{|c|c|c|c|c|}
\hline \multirow{2}{*}{ Alat Tangkap } & \multicolumn{3}{|c|}{ Zona } & \multirow{2}{*}{ Status } \\
\hline & $\mathrm{I}(0$ - $4 \mathrm{mil})$ & II (4 - 12 mil) & III (>12 mil) & \\
\hline Pukat tarik & & $\begin{array}{l}\text { Layur, Bloso, Kakap Merah, } \\
\text { Blambangan }\end{array}$ & & Underfishing \\
\hline Payang & & Teri, Bawal Hitam, Teri Nasi & & Overfishing \\
\hline Dogol & $\begin{array}{l}\text { Sunglir, Gurita, Bijinangka, } \\
\text { Kapas-kapas, Slanget, Sotong, } \\
\text { Kurisi, Kuniran, Petek, Karau }\end{array}$ & & & Overfishing \\
\hline $\begin{array}{l}\text { Pukat } \\
\text { arad/apolo }\end{array}$ & Peperek, Sebelah, Cumi-cumi & $\begin{array}{l}\text { Peperek, Sebelah, Cumi- } \\
\text { cumi }\end{array}$ & & Overfishing \\
\hline $\begin{array}{l}\text { Jaring Insang } \\
\text { Hanyut }\end{array}$ & & $\begin{array}{l}\text { Manyung, Tetengkek, } \\
\text { Bawal Putih, Talang, } \\
\text { Kakap, Kuro, Tongkol, } \\
\text { Tenggiri, Cucut }\end{array}$ & $\begin{array}{l}\text { Manyung, } \\
\text { Tetengkek, Bawal } \\
\text { Putih, Talang, } \\
\text { Kakap, Kuro, } \\
\text { Tongkol, Tenggiri, } \\
\text { Cucut }\end{array}$ & Overfishing \\
\hline $\begin{array}{l}\text { Jaring Insang } \\
\text { Lingkar }\end{array}$ & & $\begin{array}{l}\text { Japuh, Tembang, Julung- } \\
\text { Julung, Siro, Bilis }\end{array}$ & & Overfishing \\
\hline $\begin{array}{l}\text { Jaring Insang } \\
\text { Tetap }\end{array}$ & $\begin{array}{l}\text { Golok-golok, Belanak, Tigawaja, } \\
\text { Kembung, Bentong, Banyar, } \\
\text { Selar, Bawal Putih, Bandeng, } \\
\text { Ekor Kuning }\end{array}$ & & & Underfishing \\
\hline Trammel Net & $\begin{array}{l}\text { Lidah, Udang Putih, Udang } \\
\text { Dogol, Udang Krosok, Rajungan, } \\
\text { udang Lain, Kakap Putih, Udang } \\
\text { Windu }\end{array}$ & $\begin{array}{l}\text { Lidah, Udang Putih, Udang } \\
\text { Dogol, Udang Krosok, } \\
\text { Rajungan, udang Lain, } \\
\text { Kakap Putih, Udang Windu }\end{array}$ & & Underfishing \\
\hline Bagan Tancap & Teri & & & Overfishing \\
\hline Anco & Rebon, Ikan Lainnya & & & Underfishing \\
\hline Rawai Tetap & & Pari, Alu-alu, Remang & & Overfishing \\
\hline $\begin{array}{l}\text { Perangkap } \\
\text { Kerang }\end{array}$ & Kerang Dara & & & Underfishing \\
\hline $\begin{array}{l}\text { Perangkap } \\
\text { Lainnya }\end{array}$ & $\begin{array}{l}\text { Kerang Hijau, Binatang Air } \\
\text { Lainnya }\end{array}$ & & & Underfishing \\
\hline
\end{tabular}




\section{IMPLIKASI KEBIJAKAN}

Dari uraian diatas jelas, bahwa status pemanfaatan sumber daya ikan di perairan laut kabupaten Cirebon, baik menurut penggunaan jenis alat tangkap, zona penangkapan ikan maupun jenis ikan pada umumnya telah melebihi jumlah alat tangkap optimum $\left(f_{\text {opt }}\right)$ dan nilai MSY. Hal ini juga sesuai dengan hasil penelitian terdahulu di sekitar wilayah perairan Cirebon (seperti Nurhakim et.al., 1995; Gardenia, 2006; and Wiadnyana et.al., 2010).

Oleh sebab itu, untuk memelihara keberlanjutan (sustainability) dari sumber daya ikan laut dan usaha perikanan tangkap di kabupaten Cirebon, maka perlu pengurangan upaya tangkap, khususnya untuk 7 jenis alat tangkap yang telah melampaui $f_{\text {opt }}$ nya, dan di Zona-1 dan ZonaII. Kebijakan ini akan berimplikasi pada pengurangan jumlah kapal ikan dan nelayan yang dapat beroperasi di kabupaten Cirebon.

Kelebihan kapal ikan dan sebagian nelayan itu dapat dipindah-usahakan ke wilayah-wilayah laut Indonesia yang masih underfishing, khususnya di perairan laut yang selama ini berlangsung IUU (Illegal, Unregulated and Unreported) fishing oleh kapal ikan asing. Kebijakan ini diharapkan dapat berkontribusi terhadap upaya pemberantasan IUU fishing, dan sekaligus memberikan peluang bagi sumber daya ikan yang telah overfishing untuk pulih kembali di perairan laut kabupaten Cirebon.

Sementara itu, sebagian nelayan lainnya harus dilatih dan ditingkatkan kapasitasnya untuk beralih ke matapencaharian lain yang lebih menguntungkan, seperti budidaya tambak, budidaya laut, industri pengolahan hasil perikanan, dan industri dan jasa penunjang perikanan.

\section{KESIMPULAN}

1. Status pemanfaatan sumber daya ikan baik di Zona-I, Zona-II maupun Zona-III Perairan Laut Cirebon pada umumnya telah mengalami overfishing ( tangkap lebih).

2. Dari 13 jenis alat tangkap yang digunakan oleh nelayan di daerah penelitian, tujuh diantaranya yakni payang, dogol, pukat arad, jaring insang hanyut, jaring insang lingkar, bagan tancap, dan rawai tetap statusnya sudah berlebih. Sedangkan, enam jenis alat tangkap lainnya, yaitu pukat tarik, jaring insang tetap, jaring kantong, anco, perangkap kerang, dan perangkap lainnya statusnya masih kurang.

3. Jenis-jenis ikan yang telah mengalami overfishing adalah: teri, teri nasi, bawal hitam, sunglir, gurita, biji nangka, kapaskapas, slanget, sotong, kurisi, kuniran, peperek, kurau, ikan sebelah, cumicumi, manyung, tetengkek, bawal putih, talang, kakap, tongkol, tenggiri, cucut, japuh, tembang, julung-julung, siro, bilis, pari, alu-alu, dan remang.

4. Perlu pengurangan upaya tangkap untuk tujuh jenis alat tangkap dan di Zona-I dan Zona-II. Selanjutnya, kelebihan nelayan akibat kebijakan ini bisa dipindahusahakan ke wilayah laut Indonesia lainnya yang masih underfishing atau dialih-usahakan ke matapencaharian lain yang lebih menguntungkan.

\section{DAFTAR PUSTAKA}

Berkes, F., R. Mahon, P. McConney, R. Pollnac, and R. Pomeroy. 2001. Managing Small-scale Fisheries Alternative Direction and Methods. International Development Research Centre. Ottawa, Canada. 
Charles, A.T. 2001. Sustainable Fishery Systems. Blackwell Science, Osney Mead, Oxford, UK.

DKP Kab. Cirebon. 2001. Laporan Tahunan Dinas Kelautan dan Perikanan Kabupaten Cirebon Tahun 2000. DKP Kab. Cirebon, Cirebon.

DKP Kab. Cirebon. 2002. Laporan Tahunan Dinas Kelautan dan Perikanan Kabupaten Cirebon Tahun 2001. DKP Kab. Cirebon, Cirebon.

DKP Kab. Cirebon. 2003. Laporan Tahunan Dinas Kelautan dan Perikanan Kabupaten Cirebon Tahun 2002. DKP Kab. Cirebon, Cirebon.

DKP Kab. Cirebon. 2004. Laporan Tahunan Dinas Kelautan dan Perikanan Kabupaten Cirebon Tahun 2003. DKP Kab. Cirebon, Cirebon.

DKP Kab. Cirebon. 2005. Laporan Tahunan Dinas Kelautan dan Perikanan Kabupaten Cirebon Tahun 2004. DKP Kab. Cirebon, Cirebon.

DKP Kab. Cirebon. 2006. Laporan Tahunan Dinas Kelautan dan Perikanan Kabupaten Cirebon Tahun 2005. DKP Kab. Cirebon, Cirebon.

DKP Kab. Cirebon. 2007. Laporan Tahunan Dinas Kelautan dan Perikanan Kabupaten Cirebon Tahun 2006. DKP Kab. Cirebon, Cirebon.

DKP Kab. Cirebon. 2008. Laporan Tahunan Dinas Kelautan dan Perikanan Kabupaten Cirebon Tahun 2007. DKP Kab. Cirebon, Cirebon.

DKP Kab. Cirebon. 2009. Laporan Tahunan Dinas Kelautan dan Perikanan Kabupaten Cirebon Tahun 2008. DKP Kab. Cirebon, Cirebon.
DKP Kab. Cirebon. 2010. Laporan Tahunan Dinas Kelautan dan Perikanan Kabupaten Cirebon Tahun 2009. DKP Kab. Cirebon, Cirebon.

FAO. 1995. Code of Conduct for Responsible Fisheries. Rome, Italy. The recommended by International Conference on Responsible Fishing, Cancun, Mexico in 1992.

Gardenia, Y.T. 2006. Teknologi Penangkapan Pilihan Untuk Perikanan Rajungan di Perairan Gebang Mekar, Kabupaten Cirebon. Tesis. Sekolah Pasca Sarjana, Institut Pertanian Bogor.

Gulland, J.A. 1983. Fish Stock Assessment : A Manual of Basic Methods. Wiley-Interscience, New York.

Komisi Nasional Pengkajian Stok Sumberdaya Ikan. 2010. Laporan Tahunan 2010. Pusat Penelitian Pengelolaan Perikanan dan Konservasi Sumberdaya Ikan. Badan Litbang Kelautan dan Perikanan. Kementerian Kelautan dan Perikanan.

Nurhakim, S., B. Sadhotomo \& M. Potier. 1995. Composite model on small pelagic resources in Potier, M \& S. Nurhakim (Eds.). 1995. Biology, Dynamics, Exploitation of the Small Pelagic Fishes in the Java Sea. p. $145-153$.

Pusat Data Statistik, dan Informasi Kelautan dan Perikanan. 2011. Data Indikator Kinerja Umum Kelautan dan Perikanan 2010. Kementerian Kelautan dan Perikanan.

Potier, M. and B. Sadothomo. 1994. Seiners Fisheries in Indonesia. Present Document Report Seminar of Biology, Dynamics, Exploitation of the Small Pelagic Fishes in the Java Sea, 46. 
Schaefer, M.B. 1954. Some Aspects of Dynamics of Populations Important To The Management of Commercial Marine Fisheries. Bulletin of THE InterAmerican Tropical Tuna Commission, 1 , 27-56.

Schaefer, M.B. 1957. Some Considerations of Population Dynamics and Economicsin Relation to The Management of Marine Fisheries. Journal of the Fisheries Research Board of Canada, 14, 669-681.
Singarimbun, M. dan S. Effendi. 1989. Metode Penelitian Survai. LP3ES. Jakarta

Walpole, R. E. 1995. Pengantar Statistika. Edisi Ke-3. Gramedia Pustaka Utama. Jakarta.

Wiadnyana, N.N., Badrudin dan Aisyah. 2010. Tingkat pemanfaatan sumber daya ikan demersal di wilayah pengelolaan perikanan laut Jawa. Jurnal Penelitian Perikanan Indonesia. Pusat Penelitian Pengelolaan Perikanan dan Konservasi Sumber Daya Ikan. Badan Penelitian dan Pengembangan Kelautan dan Perikanan. 16 (4): 275 - 283. 